\title{
LEGAL CAPACITY, INSTITUTIONAL STRUCTURE, PRIVILEGES AND IMMUNITIES OF CUSTOMS COOPERATION COUNCIL
}

Representatives of the theory and practice of most of the world are interested in activities of The Customs Cooperation Council, also known as the World Customs Organization. Because the Customs Cooperation Council is a universal multilateral international organization in the field of customs affairs, the members of which as of December 2019 there are 183 independent participants in international customs relations. In view of this, the article analyzes the legal capacity, privileges and immunities of the Customs Cooperation Council and investigates its internal institutional structure, based on a thorough elaboration of the text of the Convention on the Establishment of the Customs Cooperation Council of 15 December 1950, of the official sites of the Customs Cooperation Council and the Organization of Customs United Nations, as well as scientific and educational works of Ukrainian and foreign scientists. Based on the results of the study, the following results were obtained. The legal capacity, privileges and immunities of the Customs Cooperation Council are limited, functional in nature, that is, they are granted with the aim of achieving the goals and tasks set for the organization, as well as fulfilling the functions assigned to it. It is appropriate to divide the capacity of the Customs Cooperation Council into international legal and private legal. The privileges and immunities of the Customs Cooperation Council are apppropriate to be classified into three groups: 1) the privileges and immunities conferred on the Council; 2) the privileges and immunities conferred on the officials of the Council; and 3) the privileges and immunities of the representatives of the members of the Council, as well as the advisers and experts who are with them. The internal institutional structure of the Customs Cooperation Council is formed by an extensive system of bodies, which can be classified into three types, namely: representative bodies (Council, General Political Commission and Financial Committee); administrative (General Secretariat); executive (Standing Technical Committee, as well as other committees, subcommittees and various working groups).

Key words: Customs Cooperation Council, World Customs Organization, legal capacity, privileges, immunities, Council, General Political Commission, Finance Committee, Secretariat, Permanent Technical Committee.

JEL Classification: K33.

Sergei PEREPYOLKIN, Head of the Department of International Law, University of Customs and Finance, Candidate of Law, Associate Professor psm-13@ukr.net

\section{Introduction}

The Customs Cooperation Council (hereinafter - CCC) is a universal international intergovernmental organization, the members of which are the vast majority of states recognized at the present stage of development of the international customs relations, the governments of individual customs territories, authorized by the states wich are members of the CCC to independently engage in foreign trade and also by the European Union. Formed to promote co-operation between the governments of its members, the CCC effectively engages with each of them and develops international co-operation 
relations with other independent actors in international customs relations. In order to maximize progress in such relations, in particular to ensure the highest level of harmonization and uniformity of customs systems of the CCC members and to strengthen the study of problems arising in the course of development and improvement of customs technique and customs legislation, the founding states of the organization have identified in the Convention about the creation of the CCC of December 15, 1950, its legal capacity, privileges and immunities, and provided for the possibility of creating the internal bodies system wich are necessary for achieving the goals of the Convention. It should be noted that, despite more than significant importance for ensuring the effective functioning of the $\mathrm{CCC}$, the detailed characterization of the above provisions in the doctrine of international customs law was hardly paid attention. In view of this, the topic chosen for the study is relevant and needs more thorough scientific discussion.

\section{Literature review}

Problems related to the activities of the CCC have been studied by scientists from different countries for a long time now. In most cases, it receives little attention in the context of complex research on various aspects of intra-state customs. For the most part, their authors describe the achieved results of the CCC activity or determine the changes expected from such activity in intra-state customs law and related to it branches of law, without taking into account the characteristics of such constituent elements of the status of the CCC as its legal capacity, privileges and immunities. Regarding the institutional structure of an organization, within the framework of the general characteristics of the organization, researchers often mention the existence of its main bodies. However, it is extremely rare for them to reveal the powers available to such bodies, and to indicate the existence of other bodies belonging to the institutional structure of the CCC.

In particular, Kafeero Ed. (2009) mentions the activities of the CCC in terms of the characteristics of the International Convention on the Simplification and Harmonization of Customs Procedures of 18 May 1973, revised under its auspices.

Cheng Ch.-J. (2010) describes the CCC in interaction with the World Trade Organization (hereinafter referred to as the WTO), and emphasizes that the CCC and the WTO not only develop international and national customs law, but also create their material sources, which form an essential part of the new rules of international and national customs law. H.-M. Wolffgang and Ch. Dellimore (2012), characterizing the interaction of CCC and WTO, suggest that within its boundaries WTO will deal with higher-level aspects while leaving implementation for CCC.

Weerth, C. (2009), revealing the structure and functions of the CCC, believes that the best example of a long-lasting interaction between the CCC and the WTO is the successful functioning of two technical committees under the auspices of the CCC, namely: the Technical Committee on Customs Valuation, established to ensure uniformity at the technical level in the interpretation and application of the Agreement on the Application of Article VII of the GATT (Article 18 of the Agreement) and of the Technical Committee on Rules of Origin, established to ensure uniformity at the technical level in the interpretation and application of the WTO Agreement on Rules of Origin (Art. 4 of the Agreement).

Within the general characteristics of the function of the CCC, scientists from the Russian Federation and other states formed in the territory of the USSR also mention in their research about the main bodies of this organization. The most famous of them are: Zhamkoch'jan S. (2006), Zhivenko N. (2007), Rajkova A. (2009), Grebennikov A. (2012), Buvaeva N. (2013)

Repeatedly, CCC and its results of activity have become the subject of research by Ukrainian scientists too. However, for the most part, such studies were descriptive, highly specialized, or unrelated to law. The most meaningful study of these is the scientific work of Muzyka Ja. 
(2015), who in a descriptive form writes about the legal capacity, privileges and immunities of the CCC to the extent that they are defined by the 1950 Convention on the creation of the CCC. Denysenko S. (2015), reviewed the activities of the CCC and the WTO in the aspect of international legal regulation of simplification and harmonization of customs procedures in the field of international trade. Chencov V. (2012), has characterized the activity of the CCC from the position of the public administration of customs business. Berezhnjuk I. (2009), explored the CCC as an institute of customs regulation in the conditions of economic globalization, and Ghrebeljnyk O. (2005), explored the CCC as one of the main subjects of customs and tariff regulation of foreign economic activity.

\section{Research methodology}

The research methodology is based on an approach to interpreting the legal personality of international organizations established in the theory of international law, and within which the legal capacity, privileges and immunities are granted to organizations in order to maximally assist them in carrying out their functions, and the institutional structure is created to ensure the functioning of the organization in general. The text of the 1950 Convention on the Establishment of the CCC, its official website and the United Nations website was analyzed, which revealed the incorrectness of the official translation into Ukrainian the name of art. II Annex to the Convention on the establishment of the CCC 1950. Scientific works of foreign and Ukrainian scientists in this field have been studied.

\section{Empirical results}

According to the text of Art. XIII of Convention on the Establishment of the CCC (1950): «The Council shall enjoy, in the territory of each of its Members, such legal capacity, as defined in the Annex to the present Convention, as may be necessary for the exercise of its functions. The Council, the representatives of Members, the advisers and experts appointed to assist them, and the officials of the Council shall enjoy the privileges and immunities specified in the Annex to the present Convention.». Let us describe in more detail the legal capacity, privileges and immunities that the Customs Cooperation Council (hereinafter - the CCC or the Council) is endowed with.

Legal capacity is an integral part of the legal characterization of an international organization as a subject of international law, and which clearly defines its ability to fulfill its goals, objectives and functions. In view of this, the legal capacity of international organizations is limited, functional in nature. It should be noted that the legal capacity limitatness is one of the main differences that distinguishes the legal capacity of international organizations, as derivative subjects of international law, from the universal legal capacity of states as the main subjects of international law.

There is no uniform approach to understanding the legal capacity of international organizations in the theory of international law.

Moraveckij V. (1976) is one of the representatives of approach according to which the international legal capacity of an international organization is equated with its international legal personality and is considered as a phenomenon that arises from the nature of the functions of this organization and that acts when these functions require autonomous activity of the organization in the field of international law.

Representatives of another approach, in particular the author's collective of a textbook on international law, edited by Butkevych V. (2004), consider that international legal capacity is only one of the structural elements of international legal personality. Its role in the system of elements of the international legal status of an international organization should be considered in terms of ownership of an international organization by some general rights, which means 
the ability to have specific rights and obligations stipulated by the rules of international law for participants in this type of international legal relations.

In the case of the legal capacity of the CCC, its member states have granted its SecretaryGeneral the right to act on behalf of the Council in the following areas: to conclude agreements; acquire and dispose of immovable and movable property; to prosecute.

At the same time, if you are acquainted with the abovementioned $\mathrm{CCC}$ rights, which are enshrined in the text of the Annex to the Convention on the establishment of the CCC «Legal capacity, privileges and immunities of the Council», on the official site of the Verkhovna Rada of Ukraine «zakon.rada.gov.ua» (1992), you can see that they are listed in the article entitled «Legal personality». At the same time, if we refer to the official text of this Convention, which is presented in French and published on the official site of the CCC, we can see that in its contents the corresponding article is entitled «PERSONNALITE JURIDIQUE» (1950), which will be translated in Ukrainian as «LEGAL PERSON».

In our opinion, the use of the name «Legal personality» does not correspond to the content of the article and is incorrect. Therefore, in order to properly interpret the provisions of Art. II «PERSONNALITE JURIDIQUE» Annex to the Convention on the Establishment of the CCC «Legal capacity, privileges and immunities of the Council», incorrect title of Art. II. «Legal personality» in its translation into the Ukrainian language published on the official site of the Verkhovna Rada of Ukraine in its content shall be corrected to «LEGAL PERSON», which more accurately characterizes the rights of the CCC.

The title of Article II «LEGALPERSON» of the Annex to the Convention on the Establishment of the CCC «Legal Capacity, Privileges and Immunities of the Council» matches the official translation of the same name and almost identical in meaning to Art. 1 «LEGAL PERSON» of the United Nations Convention on the Privileges and Immunities of 13 February 1946 (1946), which further confirms the relevance of our proposal.

Also it should be noted that the above clarification of the name of Art. II of the Annex to the Convention on the Establishment of the CCC «Legal capacity, privileges and immunities of the Council» will help to differentiate the legal capacity of the CCC as a subject of international law from its legal capacity as a legal entity of the international private law, which is discussed in the text of analized by us article .

As another confirmation of existence of the legal capacity in the CCC in the sphere of private legal relations can be cited the following provisions of Section 24 of the Article IX «Dispute Resolution» of the Annex to the Convention on the Establishment of the CCC «Council's Legal Capacity, Privileges and Immunities»: «The Council shall make provision for appropriate modes of settlement of: a) disputes arising out of contracts or other disputes of a private character to which the Council is a party; b) disputes involving any official of the Council who by reason of his official position enjoys immunity, if immunity has not been waived in accordance with the provisions of Sections 19 and 21.» (1950)

With respect to the legal capacity of the $\mathrm{CCC}$ as a subject of international law, in accordance with the provisions of the Convention on the Creation of the CCC, the organization may enter into relations with other international intergovernmental and non-governmental organizations as well as with another states. The following provisions of the founding act of the CCC can be considered as confirmation of this: «The Council shall establish such relations with the United Nations, its principal organs, subsidiary bodies and specialized agencies, and any other inter-governmental organizations, as may best assure collaboration in the achievement of their respective tasks. The Council may make arrangements necessary to facilitate consultation and cooperation with non-governmental organizations interested in matters within its competence... 
The Council may conclude with any Contracting Party or Contracting Parties supplementary agreements adjusting the provisions of the present Annex so far as that Contracting Party or those Contracting Parties are concerned.» (1950)

It should be emphasized that in the case of the Council's right to conclude additional agreements with the Contracting Parties to the Convention on the establishment of the CCC, that is, with the contractual legal capacity of the organization, it does not clearly specify which agreements are in question, nor does it specify which law governs the relations on which such agreements are conclude. Based on the practice of the $\mathrm{CCC}$, it can be said that these may be agreements that fall under the legal regulation of private international law, as well as international treaties concluded and enforced on the basis of public international law.

About the contractual legal capacity of international intergovernmental organizations Professor Syrojid T. (2018), states the following: international intergovernmental organizations conclude treaties regarding their headquarters and their missions with the host countries, cooperation agreements in accordance with their statutory objectives, technical assistance agreements, succession and other. The international legal personality of intergovernmental organizations is also reflected in the fact that, as mentioned above, there are state representations at international organizations; international organizations and their officials enjoy privileges and immunities; they have international legal liability in the case of wrongdoing and the like.

Another, equally important, element of the status of CCC is the privileges and immunities accorded to the organization and its staff in their relations with the host country and the member states.

As with other international organizations, the privileges and immunities of the $\mathrm{CCC}$, its officials and its members are functional in nature. That is, they are provided to fulfill the goals and objectives set for the organization, as well as to eliminate obstacles in the performance of by officials and representatives of its members its functions, which may be created by the authorities of the host State of the international organization headquarters.

The authors of a textbook on international law, edited by Butkevych V. (2004), point out that the need for granting privileges and immunities to an international organization and its staff also stems from the fact that the organization, as a rule, does not have its territory and is located in the territory of a member state and sometimes of a non-member of the organization.

The privileges and immunities of the CCC include: the inviolability of the Council's headquarters, its archives and, in general, all documents belonging to it or in its possession; immunity from jurisdiction over the property and assets of the Council, whoever had them and whenever they are, unless the organization expressly waives it; the property and assets of the Council, whoever had them and whenever they are located, are immune from search, requisition, confiscation, expropriation and from any other form of interference by the executive, administrative, judicial or legislative branches of power; its funds, income and other property are exempt from all direct taxes except taxes, the amount of which does not actually exceed utility bills; printed materials and articles imported or exported by the Council for official purposes are exempt from duty; The Council may not be restricted in the conduct of financial transactions in any currency, both within one country and international transfers; the Council's official correspondence and other official communications are not subject to censorship; the council may count on the exemption from excise duty, duties or taxes included in the price to be paid for the sale of movable property; for the purpose of official communication, the Council shall enjoy in the territory of each of its members a regime no less favorable than that which may be accorded by that member of the Council to any other Government, including its diplomatic mission, with regard to the priority, tariffs and fees of postal items, different kinds of telegrams, radiograms, telex, telephone and other communications, as well as tariffs for information messages in the press and on the radio (1950). 
The members of the CCC are accorded the following privileges and immunities: immunity from arrest or detention and search of personal luggage, as well as from words expressed or written and any action made by them in their official capacity, immunity from prosecution; inviolability of personal luggage and all materials and documents; release of themselves and spouse (husband) from immigration restrictions or registration in the country to which or through which they are sent in the exercise of their functions; the right to use ciphers and to receive materials and correspondence by courier or in sealed suitcases; the same regime with respect to currency or exchange restrictions as is accorded to representatives of foreign governments on temporary official missions.

It is important to note that the privileges and immunities of Council officials are not the same for all its staff. Thus, the privileges and immunities conferred on the Council's full-time officials include the duty-free importation of furniture and belongings upon initial entry into the country of destination and the right of duty-free exportation of these furniture upon return to the country of permanent residence upon expiry of their term of office; immunity from prosecution for words uttered or written and for any acts committed by them in their official capacity and within the scope of their authority; exemption from payroll tax and remuneration paid to them by the Council; immunity for them, together with spouses and relatives, from immigration restrictions and registration; privileges for exchange operations; the privilege of using with their spouses and dependents the same opportunity for repatriation in times of international crisis as officials of diplomatic missions of similar rank.

Compared to full-time officials, the General Secretary of the Council and his deputy are more empowered in exercising their own functions. In addition to the above privileges and immunities, the Secretary-General of the Council shall enjoy in respect of himself, his wife and children under 21 the privileges and immunities, benefits and rights conferred on international heads of diplomatic missions of a similar rank.

In the case of experts who carry out the tasks of the Council, they shall, for an appropriate period, be accorded the following privileges and immunities in order to provide them with the necessary conditions for the independent exercise of their functions during the performance of the task, including the period of official travel in connection with those tasks: immunity from arrest or detention and search of personal luggage; not to be held accountable for words spoken or written, or actions made in the course of the performance of their duties and within the scope of their authority; immunity from all kinds of prosecutions; inviolability of all materials and documents (1950).

It should be noted that, as in the case of Council officials, privileges and immunities are conferred on experts not for their own benefit, but for the benefit of the CCC. As in the case of Council officials, the General Secretary may deny the immunity of any expert if, in his opinion, immunity could interfere with the administration of justice and if it would not prejudice the interests of the Council.

The General Secretary constantly cooperates with the relevant authorities of the members of the Council in creating the conditions for the proper administration of justice, ensuring public order and preventing any abuse of privileges, immunities and rights.

If there are grounds for alleging abuse of privileges by Council officials, not in the performance of their duties, they may be required to leave the country. However, at the same time: 1) the representatives of the members of the Council, the Deputy General Secretary or the wife and children of the General Secretary of the Council under the age of 21 may not be required to leave the country other than in accordance with the diplomatic procedure applicable to diplomatic agents in that country; 2) in respect of other officials of the Council, the decision to leave the country may not be taken otherwise than with the approval of the Minister for Foreign Affairs of that country, and such approval must be obtained only after consultation with the General 
Secretary of the Council, and in the event that the expulsion procedure applies to the official The General Secretary of the Council shall have the right to enter into such proceedings on behalf of the person against whom he or she was violated.

A final component of this study is the characterization of the institutional structure of CCC, which consists of an extensive system of bodies of various purposes and composition. As we noted earlier in the monograph «International Law of the 21st Century: Current Status and Prospects for Development (to the 60th Anniversary of Prof. Repetsky V.)» (2013), taking into account the scope of competence, their number varied according to the needs of international legal regulation of customs relations, occurring at different stages of the organization, and the composition of the representation depended on an increase in the number of States parties and their interest in solving specific customs issues.

In this regard, it is proposed to consider the current structure and competence of the existing internal organs of the CCC, which, as noted by Wolfgang G.-M. and Dallimore K. (2012), has a complex hierarchy.

Muzyka Ja. (2015), for example, considers that all organs belonging to the internal organizational mechanism of CCC can be divided into two groups: the main and the subsidiary (technical). The first group includes those bodies whose creation and functioning are foreseen by the 1950 Convention on the Establishment of the CCC, namely: the Council, the Secretariat and its departments, the Secretary General of the Permanent Technical Committee. The author also considers it appropriate to include those bodies whose establishment and operation are not expressly provided for in the Convention, but which play a leading role in the activities of the Organization - the Political Commission and the Finance Committee. The second group includes committees, subcommittees and working groups established and operating within the Organization to directly achieve its goals and functions.

We, for our part, consider it appropriate to divide all existing internal organs of CCC into: representative; administrative and executive. The supreme body of the organization, and the most important representative body of the organization, which makes the final decisions concerning its work and to which all other bodies are accountable, is the Council. The Council shall be composed of representatives of the States Parties and shall convene at least twice a year. In practice, the Council meets once a year, usually at the end of June. However, during its convening, the Council reviews the materials of its two sessions. Each state has one vote and can be represented by one delegate, who may have one or more alternates, as well as advisers. Representatives of Governments, who are non-members, may also observe the work of the Council. The Council annually elects from among the delegates of the members of the Council the Chairman and his deputies, the number of which depends on the number of regional offices of the organization. Decisions of the Council shall be taken by a majority of two-thirds of the votes of its members present, who, moreover, shall be entitled to vote.

The members of the Board shall provide it with any information and documents upon request, necessary for the performance of its functions, provided that no member will be required to provide classified information, the disclosure of which would impede the application of its laws or otherwise contravene public interests or affect the legitimate commercial interests of any enterprise, whether public or private. Each participating country bears the costs of sending its delegation to the Council, the Standing Technical Committee or other committees. The Council determines the scale of expenditure of its member countries. The Council has the right to withdraw the voting right of a Member State in the event of non-payment of the contribution within three months after receiving the notification of its size. Each Member State pays its full annual contribution in the financial year during which it becomes a Member of the Council, as well as in the financial year during which notification of its waiver becomes effective. 
Global trends in trade, transport, technology have had a significant impact on the definition of the following major areas of activity of the senior CCC representative body at the internal organizational level: consideration and, if necessary, approval of the results of the work of the working bodies of the CCC, including the preparation or amendment of the CCC documents; consideration, on the basis of the Secretary-General's written and oral reports, the progress made over the previous 12 months as a result of the activities of the CCC, the implementation of the 3 -year strategic plan; identifying the future directions of the CCC, in particular by reviewing, refining and adopting a strategic plan, which is prepared annually by the Secretariat and submitted to the Council after prior consideration by the General Political Commission; interpretation of the provisions of the Convention establishing the Customs Cooperation Council; providing a forum at the highest level for the exchange of information, opinions and experience on topical issues in the customs field; making budgetary and financial decisions based on recommendations provided by the Finance Committee; election of the Chairman of the Council and the deputies of the Chairman of the Council, members of the General Political Commission, the Chairman, deputy chairmen and members of the Finance Committee; the appointment of the SecretaryGeneral and the Deputy Secretary-General of CCC; adoption of the schedule of meetings of the $\mathrm{CCC}$ for the next year.

Along with the characteristics of the Council, its representative bodies such as the General Political Commission and the Finance Committee, whose work as a whole is aimed at ensuring the functioning of the $\mathrm{CCC}$, deserve special attention.

Bouvaeva N. (2013), for its part, believes that these bodies are subsidiary bodies of the Council. There are no references to them in the Convention on the establishment of the CCC, but their formation and activities do not contradict its provisions, the scientist said.

The General Political Commission (hereinafter referred to as the Commission) was established in 1978 and must meet at least twice a year. Its mandates include discussing important issues in the functioning and development of the world customs system, which are further submitted to the Council for consideration: development, implementation and renewal of international conventions and other legal instruments in the field of customs, the implementation of CCC resolutions on security and international trade facilitation, a strategy to enhance the capacity of the customs services, issues of the Harmonized System. The commission approves the functioning and the plans of work of the working bodies of the organization, and also considers the issues of its strategic planning. The Commission may, within the limits of its competence, make recommendations to the Council and, in matters requiring urgent resolution, request the Secretary-General of the Council to take such actions as the Commission considers necessary in the interests of the Council.

Membership of the Commission is limited to 24 representatives, of which 17 are elected on a regional basis by the most active members of a particular region, and the seats of the other 7 are held by the Chairman of the Council and his alternates. The members of the Commission shall be elected by the Board for a two-year term, and the Chairman and alternates for a term of one year. As a rule, the meetings of the Commission are attended by customs officials or their deputies.

Berezhnyuk I. (2009) notes the decisions of the Commission, which need financing, before their consideration at the sessions of the Council, to the Finance Committee, which resolves these issues.

The Finance Committee is an elected body, formed by a universal vote of CCC members at its 17-member sessions. The Committee has the following tasks: to control the correctness of the financial expenditures of the CCC funds by its Secretary-General and the persons to whom 
he has the power to delegate the signing of the financial expenditure documents of the CCC Secretariat; prepare financial documents (in revenue and expenditure) for the CCC session on the amount of financial annual contributions to CCC from member countries and on the costs of $\mathrm{CCC}$ activities for the following year.

The Finance Committee holds its meetings depending on the needs and decisions of CCC sessions, but at least once a year. At its (annual) meeting, the Finance Committee makes a financial assessment (based on audit materials) of the activities of the CCC Secretariat and draws up a financial annual project (profits and expenses) of the CCC based on political decisions made by the Political Commission.

The election of any country as a member of the CCC Finance Committee, and moreover of its General Political Commission, has always been and remains a sign of great respect for its customs service and customs administration by all CCC members, including its customs region.

The permanent secretariat of the CCC is the General Secretariat. The main function of the General Secretariat is to coordinate the CCC. The Secretariat ensures the fulfillment of the primary mission of assisting and assisting States parties in their cooperation, facilitating the implementation of the Council's decisions. This body prepares documents and reports, organizes meetings, conducts various activities, coordinates the provision of technical assistance and training activities. The General Secretariat has its structure: heads the Secretary General of the $\mathrm{CCC}$, who has an alternate; the management unit includes the communications, administration and financial services of the Secretariat; The Institutional Development Directorate coordinates the implementation of the COLUMBUS program and training; The Directorate of Tariffs and Trade provides assistance in customs valuation, nomenclature maintenance, rules of origin; The Customs Enforcement and simplification directorate assists in the enforcement of law enforcement and customs facilitation and harmonization.

States Parties provide the Secretariat with the necessary staff to carry out the projects. The Secretariat staff are international employees, so their job responsibilities are not confused with national ones, they are purely international. Upon receiving the appointment, the staff of the Secretariat must cease their national functions and commit themselves to work in the interests of the CCC. The Secretariat of the CCC is headed by the Secretary-General, elected by the members of the organization and appointed by the Board for a term of five years, practically embodying and acting on behalf of the CCC.

As Muzyka Ja. (2015) rightly points out, the powers of the Secretariat appear to be secondary, but it is one of the major structural elements of the World Customs Organization. Virtually every organ of the Organization interacts with the Secretariat, and the latter, in turn, performs the functions of organizational support for their activities.

All other CCC bodies, both those directly mentioned in the CCC Convention and those that actually ensure the fulfillment of the goals and objectives of the CCC, in our view, should be considered the executive bodies of that organization. To this end, the Council may establish committees which may, in turn, have subcommittees, and may set up, for their own purposes, pre-session or permanent working groups.

The CCC's executive body is the Permanent Technical Committee, which is made up of representatives from all member countries of the Organization. Each may nominate one delegate and one or more alternates to the Committee. According to Art. X of the Convention on the Creation of the CCC, representatives should be officials with specialist knowledge of customs practice, with experts. The Standing Technical Committee convenes at least four times a year. The Committee shall develop methods for simplifying and harmonizing customs legislation and procedures. 
The functions of the Standing Technical Committee include: work on the promotion, development and management of trade facilitation tools and mechanisms in accordance with the CCC Strategic Plan; promoting enhanced cooperation between customs authorities and governmental and non-governmental organizations in the area of trade facilitation; implementation and encouragement of initiatives aimed at improving the efficiency of Customs use of information technology, customs cooperation and the establishment of various legal instruments; the development of various instruments designed to enhance trade efficiency (in particular, the Guidelines for Determining the Time it takes to produce goods), as well as facilitating their use by participating countries; participation in the development of tools and methods to facilitate, simplify and harmonize customs formalities; providing strategic support to CCC capacity-building programs for its members.

The powers of the Standing Technical Committee also include the right: create such working groups as he deems necessary to assist him in the performance of his functions; to determine, in accordance with the guidelines of the CCC Council, and to direct the activities of the working bodies of the CCC, within its competence; cooperate, promote joint projects, share information and experience with international governmental and non-governmental organizations, as well as private sector business associations whose activities are related to customs procedures and trade facilitation.

To date, the International Convention on the Simplification and Harmonization of Customs Procedures, adopted in 1973, remains the most famous result of the Committee's work. In addition, the Committee conducts comparative studies, publishes a glossary of international customs terms, develops drafts of international customs conventions and provides recommendations for simplification and harmonization of customs procedures.

With regard to other technical committees operating in the structure of the CCC at this stage, Buvaeva N. (2013) divides them into a circle of investigated problems into four groups:

1. Issues of nomenclature and classification of goods for customs purposes are dealt with by the Committee on the Harmonized System, the Subcommittee on the Review of the Harmonized System, the Subcommittee on Science;

2. The problem of customs valuation of goods is resolved by the Technical Committee on Customs Valuation of Goods (served by the Agreement on the Application of Article VII of GATT) and by the Technical Committee on Customs Valuation (servicing the Brussels Convention);

3. Customs technical means are the scope of activity of the Standing Technical Committee, the Subcommittee on Automated Data Processing;

4. The issue of determining the country of origin of goods shall be considered by the Technical Committee for the determination of the country of origin of the goods.

It should be noted that in reality, the number of CCC executive bodies represented by different technical committees, subcommittees and working groups is much larger.

Having worked out the official site of the CCC, we can conclude that Having studied the official site of the CCC, it can be concluded that as of December 2019, the following CCC executive committees, subcommittees and working groups belong to the list of CCC executive bodies, which are grouped by activity within four groups, namely:

1) Tariff and trade issues: Committee on the Harmonized System; Harmonized System Review Subcommittee; Scientific Subcommittee; Working Group on Harmonized System; Technical Committee on Rules of Origin; Customs Technical Committee; Transfer Pricing Focus Group;

2) Procedures and facilitation: Permanent Technical Committee; Information Management Subcommittee; the Committee on the Revised Kyoto Convention; Administrative Committee of the Istanbul Convention; Contracting Parties to the ATA Convention; 
3) Assurance and Compliance: Executive Committee; Working Group on Commercial Fraud; Group of projects on global information and intelligence strategy; CCC Counterfeit and Piracy Group (CAP); EGovernment Expert Group;

4) Capacity Building: Capacity Building Committee; Integrity Subcommittee (2019).

Unfortunately, even a brief description of the powers of all executive bodies within our work is not possible. Therefore, by summarizing the above, it can be assured that the CCC has a branched and complex internal structure of bodies whose powers and activities generally correspond to the basic functions assigned to it by the founding States. In particular, it concerns the provision of proper conditions for the continued maintenance of the relations of international customs cooperation within the framework of its activity, as well as the normative consolidation of the results of such cooperation through the progressive development and codification of the rules of international customs law.

\section{Conclusions}

Summarizing the above, we can draw the following conclusions:

1. The legal capacity, privileges and immunities of the CCC are limited, functional in nature, that is, they are granted for the purpose of achieving the goals and tasks set for the organization, as well as fulfilling the functions assigned to it.

It is appropriate to divide the capacity of the Customs Cooperation Council into international legal and private legal. The international legal capacity of the CCC is realized in relations with other subjects of international law on various issues of their international cooperation, in particular concerning the conclusion of international agreements, holding of joint international conferences and other measures (carrying out joint operations aimed at combating international crime, overcoming the consequences of natural disasters, etc.). The private legal capacity of the $\mathrm{CCC}$ is realized mainly through the conclusion of various agreements, acquisition and alienation of immovable and movable property, violation of persecution within the national jurisdiction of the states.

2. It is appropriate to classify Privileges and immunities of the CCC into three groups: 1) the privileges and immunities conferred on the Council; 2) the privileges and immunities conferred on the officials of the Council; and 3) the privileges and immunities of the representatives of the members of the Council, as well as the advisers and experts who reside with them. Among the privileges and immunities granted to the $\mathrm{CCC}$ are the following: from the national jurisdiction of States; tax (fiscal) immunities; customs immunities; freedom of communication with both the receiving State and the $\mathrm{CCC}$, etc. In the case of abuse of privileges and immunities, the latter may be revoked and those involved in such abuse may be deported or brought to justice.

3. The institutional structure of the CCC is proposed to be classified into three types of bodies: representative bodies (Council, General Political Commission, and Finance Committee); administrative (General Secretariat); executive (committees, subcommittees and various working groups, which are divided into four groups depending on the subject of activity: tariff and trade issues: Committee on the Harmonized System; Subcommittee on the Review of the Harmonized System; Scientific Subcommittee; Working Group on Harmonized System; Technical Committees; Customs Evaluation Technical Committee; Transfer Pricing Focus Group; Procedures and Facilitation: Standing Technical Committee; Information Management Subcommittee; Revised Kyoto Convention Committee; Steering Committee of the Istanbul Convention; ATA Contracting Parties; Provision and Compliance: Executive Committee; Commercial Fraud Working Group; Global Information and Intelligence Strategy Project Team; CCC Counterfeiting and Piracy Group (CAP); Electronic Crime Expert Group; Capacity Building: Capacity Building Committee; Integrity Subcommittee). 


\section{References:}

1. Convention portant création d'un Conseil de coopération douanière (1950) - Signée à Bruxelles le 15 décembre 1950, entrée en vigueur le 4 novembre 1952. Organisation mondiale des douanes : веб-сайт. URL: http://www.wcoomd.org/-/media/wco/public/fr/pdf/about-us/legalinstruments/conventions-and-agreements/ccc/convccd.pdf?la=fr. (data zvernennja: 15.12.2019).

2. Customs Law of East Asia / ed. by Chia-Jui Cheng (2010). Kluwer Law International BV, The Netherlands. xxxvii, 555.

3. Wolffgang, Hans-Michael and Dallimore, Christopher (2012). The World Customs Organization and its Role in the System of World Trade: An Overview. European Yearbook of International Economic Law. Vol. 3, 613-633.

4. Kafeero, Ed. (2009). Customs Law of the East African Community in light of WTO Law and the Revised Kyoto Convention : Inaugural-Dissertation. Lyabuguma, Uganda, 268.

5. WCO Working Bodies. World Customs Organization (2019). : веб-сайт. URL: http://www.wcoomd.org/en/about-us/wco-working-bodies.aspx (data zvernennja 15.12.2019).

6. Weerth, C. (2009). The Structure and Function of the World Customs Organization. Global Trade and Customs Journal. Vol 4. Iss. 5, 131-154.

7. Berezhnjuk I. (2009) Mytne reghuljuvannja Ukrajiny: nacionaljni ta mizhnarodni aspekty : monoghrafija. Dnipropetrovsjk : Akademija mytnoji sluzhby Ukrajiny, 543.

8. Buvaeva, N. (2013). Mezhdunarodnoe tamozhennoe pravo : ucheb. dlja magistrov / pod obshh. red. A. V. Zubacha. Moskva : Izd-vo Jurajt, 376.

9. Ghrebeljnyk, O. (2005). Mytne reghuljuvannja zovnishnjoekonomichnoji dijaljnosti: pidruchnyk. Kyjiv : Centr navchaljnoji literatury, 696.

10. Grebennikov, A. (2012). Vsemirnaja tamozhennaja organizacija v mezhdunarodnom tamozhennom prave : ucheb. posobie. Minsk : Beltamozhservis, 64.

11. Denysenko, S. (2015). Mizhnarodno-pravovi standarty sproshchennia ta harmonizatsii mytnykh protsedur u sferi mizhnarodnoi torhivli : dys. ... kand. yuryd. nauk : 12.00.11. Odesa, 287.

12. Zhamkoch'jan, S. (2006). Tamozhennyj sojuz kak regional'naja organizacija (na primere Evropejskogo Sojuza i Evrazijskogo Jekonomicheskogo Soobshhestva): dis. ... kand. jurid. nauk: 23.00.04. Sankt-Peterburg, 216.

13. Zhivenko, N. (2007). Mezhdunarodno-pravovye osnovy tamozhennogo regulirovanija vneshnejekonomicheskoj dejatel'nosti: dis. ... kand. jurid. nauk: 12.00.10. Moskva, 172.

14. Konvencija o privilegijah i immunitetah Ob\#edinennyh Nacij. Organizacija Ob\#edinennyh Nacij. : veb-sajt. URL: https://undocs.org/ru/A/RES/22\%28I\%29 (data zvernennja: 15.12.2019).

15. Mizhnarodne pravo : osnovni ghaluzi : pidruchnyk. Butkevych V. Gh. ta in. (2004); za red. V. Gh. Butkevycha. Kyjiv : Lybidj, 816.

16. Mizhnarodne pravo KhKhI stolittja : suchasnyj stan ta perspektyvy rozvytku (do 60-littja prof. V. M. Repecjkogho) : kolekt. monoghr. / M. M. Mykivych ta in. (2013) ; za red. M. M. Mykijevycha. Ljviv : LA «Piramida», 320.

17. Moraveckij, V. (1976). Funkcii mezhdunarodnoj organizacii : per. s pol. G. B. Borina, N. G. Prudkovoj ; pod red. i s vstup. st. G. I. Morozova. Moskva : Progress, 384.

18. Muzyka, Ja. (2015). Pravovyj status Vsesvitnjoji mytnoji orghanizaciji : dys. na zdobuttja nauk. stup. kand. juryd. nauk : 12.00.11. Ljviv, 200.

19. Pro pryjednannja Ukrajiny do Konvenciji pro stvorennja Rady Mytnogho Spivrobitnyctva 1950 r. : postanova Verkhov. Rady Ukrajiny vid 19 cherv. 1992 r. \# 2479-KhII (1992) : veb-sajt. URL: https://zakon.rada.gov.ua/laws/main/995_184 (data zvernennja: 10.11.2019).

20. Rajkova, A. (2009). Mezhdunarodno-pravovye aspekty uproshhenija i garmonizacii tamozhennyh procedur (na primere mezhdunarodnyh tamozhennyh konvencij po Karnetam A.T.A.) : dis. ... kand. jurid. nauk: 12.00.10. Moskva, 189.

21. Syrojid, T. (2018). Mizhnarodne publichne pravo : pidruchnyk. Odesa : Feniks, 744.

22. Chencov, V. (2012). Mekhanizmy derzhavnogho upravlinnja mytnoju spravoju : monoghrafija. Dnipropetrovsjk : AMSU, 492. 


\section{ПРАВОЗДАТНІСТЬ, ОРГАНІЗАЦІЙНА СТРУКТУРА, ПРИВІЛЁ̈ ТА ПІЛЬГИ РАДИ МИТНОГО СПІВРОБІТНИЦТВА}

\section{Сергій ПЕРЕПЬОЛКІН}

завідувач кафедри міжнародного права

Університету митної справи та фінансів, кандидат юридичних наук, доиент psm-13@ukr.net

Теоретики та практики з усього світу зацікавлені у роботі Ради Митного Співробітництва, також відомої як Світова Митна Організація, через те, щзо це єдина різностороння міжнародна організація, у якій, станом на грудень 2019 року, налічується 183 незалежних учасники міжнародних митних відносин. 3 огляду на ие, у статті проаналізовано правоздатність, привілеї та пільги Ради Митного Співробітництва та досліджено ї̈ внутрішню організаиійну структуру на основі детального вивчення Конвениії про створення Ради Митного Співробітництва від 15 грудня 1950 року, офіиійного сайту Ради Митного Співробітництва та Організаиії Об 'єднаних Націй, а також науково-освітніх робіт українських та іноземних науковиів. По завершенню дослідження були отримані такі результати: правоздатність, привілеї та пільги Ради Митного Співробітництва обмежені, за своїм характером функціональні, тобто такі, що надаються з метою досягнення иілей та вирімення завдань організації, а також виконання ї̈ функцій. Доречно розділити сферу діяльності Ради Митного Співробітництва на вплив міжнародного та приватного права. Привілеї та пільги Ради Митного Співробітництва класифікують за трьома групами: 1) привілеї та пільги, надані Раді; 2) привілеї та пільги, надані офіційним представникам Ради; 3) привілеї та пільги, надані представникам иленів Ради, також їхнім радникам та експертам. Внутрішня організаційна структура Ради Митного Співробітництва складається з великої кількості органів, які можна розділити на три групи, а саме: представницькі органи (Рада, Комісія з Загальних Політичних Питань та Фінансовий Комітет); адміністративні органи (Генеральний Секретаріат); виконавчі органи (Постійний Технічний Комітет, а також інші комітети, підкомітети та різноманітні робочі групи).

Ключові слова: Рада Митного Співробітництва, Світова Митна Організація, правоздатність, привілеї, пільги, Рада, Комісія з Загальних Політичних Питань, Фінансовий Комітет, Секретаріат, Постійний Технічний Комітет. 